\title{
RADIOCARBON DATING OF OSTRICH EGGSHELLS
}

\section{JÜRGEN C FREUNDLICH, RUDOLPH KUPER, PETER BREUNIG}

Institut für Ur- und Frühgeschichte

and

HANS-GEORG BERTRAM

Geologisches Institut, Universität zu Köln, West Germany

\begin{abstract}
Unlike wood charcoal, as found admixed to other cultural remains, ostrich eggshells can be of more direct significance in ${ }^{14} \mathrm{C}$ dating, especially if they were processed to form, eg, eggshell beads. Normally the time span between laying the egg and working the shell beads is short enough to be negligible for ${ }^{14} \mathrm{C}$ dating purposes. Another advantage of eggshell dating is that the carbonate of the shell seems to keep exceptionally well over the millennia, whereas, especially in surface sites in a desert environment, organic material such as wood, charcoal or bone protein tends to decompose. With few comparative test samples, we thought ostrich egg samples would yield ${ }^{14} \mathrm{C}$ dates somewhat too young. The deviation is, however, balanced by performing ${ }^{13} \mathrm{C}$ analyses and a correction for isotope fractionation of ca $350 \mathrm{yr}$.
\end{abstract}

Within the scope of diverse investigations on African prehistory (Kuper, 1988; Breunig, 1986; Gabriel, 1984) the question arose whether ostrich eggshells are as reliable as other customary materials for accurate ${ }^{14} \mathrm{C}$ dating (see also, Wendorf \& Schild, 1984). This is an important consideration as, especially in desert environments, many samples come from surface sites where charcoal, bone, wood or other organic remains easily decay, whereas ostrich eggshells used in prehistoric settlements for manufacturing beads or water containers, have endured.

Along with a considerable number of ${ }^{14} \mathrm{C}$ dates from eight field seasons from 1980-1987 in the Eastern Sahara of Egypt and Northern Sudan ( $c f$, Kuper, 1988), we analyzed $>25$ eggshell samples. By comparing the apparent ostrich eggshell dates (uncorrected for isotopic fractionation) with the dates of other concurrent material, the eggshell dates were ca 400 years too young (Table 1). We concluded that this may be due to an isotopic shift and reviewed our ${ }^{13} \mathrm{C}$ measurements which indeed established this effect (Table 2).

We then compared this deviation with the results for other carbonate dates, and inferred that possibly the isotopic shifts resembled those typical for carbonate materials (ca $-10 \%$ o for freshwater carbonate and ca $0 \%$ o for carbonates of marine origin (Mook, 1968)). Taking a closer look at the $\delta^{13} \mathrm{C}$ values of the eggshells, we found an apparent separation of the isotopic shift values into two groups; some seem to cluster ca $-0.5 \pm 1.5 \%$ and the rest ca $-6.0 \pm 1.5 \%$ PDB. If there is no $\delta^{13} \mathrm{C}$ analysis, a tentative average correction for the ${ }^{14} \mathrm{C}$ age of $350 \pm 60 \mathrm{yr}$ can be applied to normalize to $\delta^{13} \mathrm{C}=-25 \%$, based on a total $\delta^{13} \mathrm{C}$ range of -7.0 to $+1.0 \%$ for ostrich eggshell carbonate. We also tried to classify the two separated $\delta^{13} \mathrm{C}$ intervals according to geographic or climatic parameters or age differences among the respective samples that failed, so far, to give a decisive clue.

The literature on isotopic effects on carbon shows that considerable interest in hens' eggs has led to the finding that the dominating factor is the ${ }^{13} \mathrm{C}$ level of the hens' food stuff, mirrored by the $\delta^{13} \mathrm{C}$ values of their flesh. 


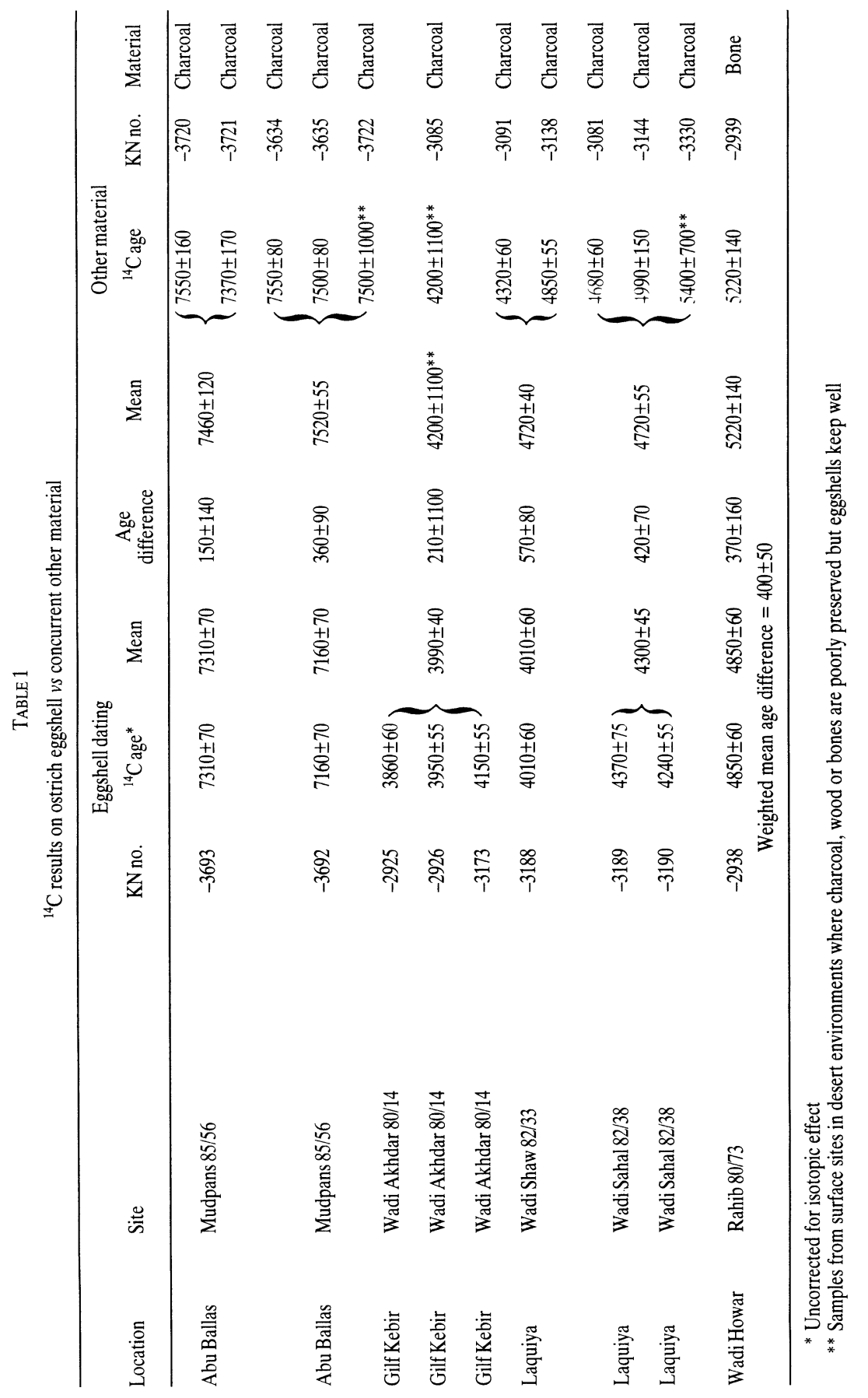




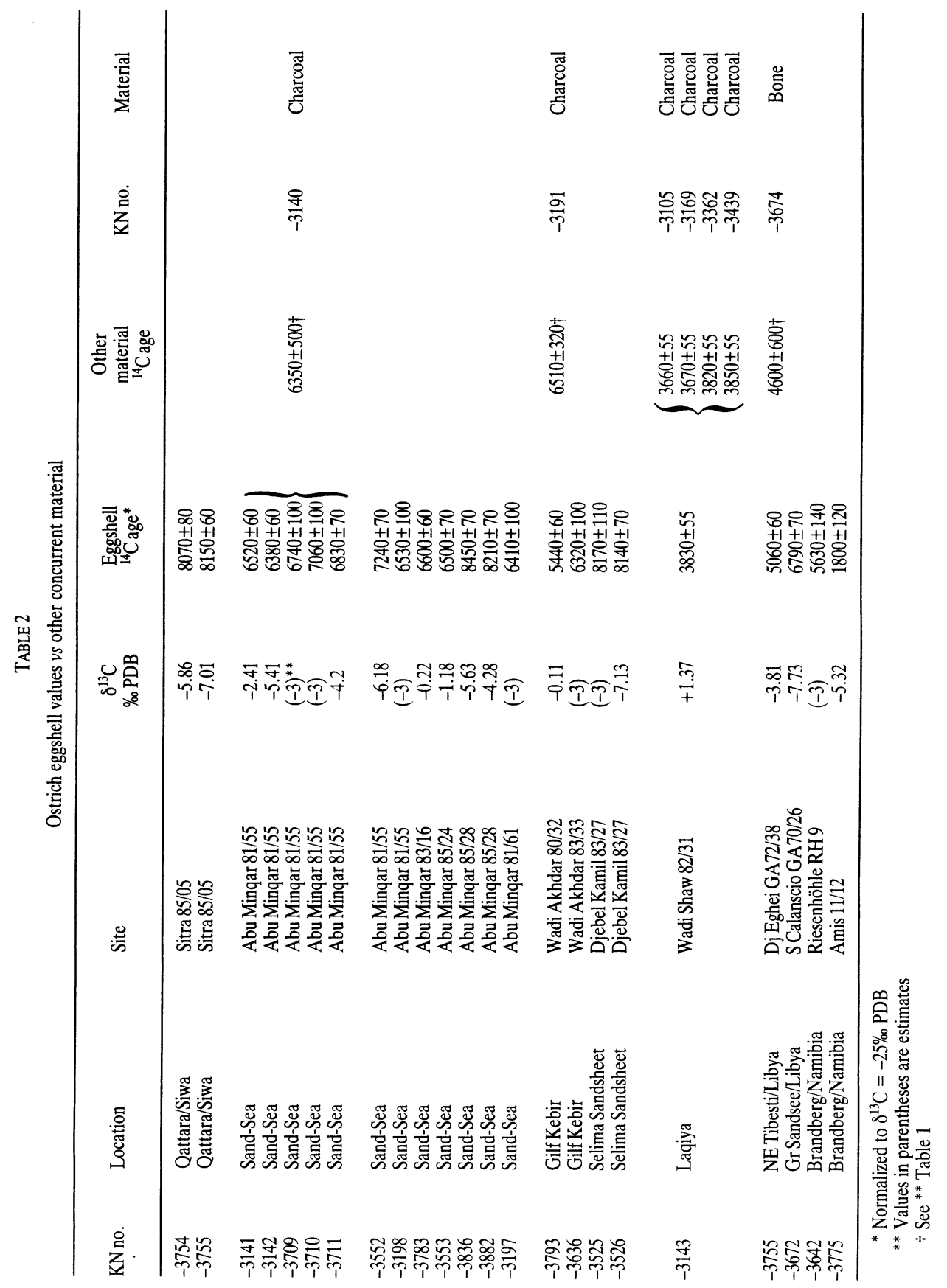


TABLE 3

$\delta^{13} \mathrm{C}$ values of chicken protein carbon

\begin{tabular}{ll}
\hline${ }^{13} \mathrm{C}(\mathrm{PDB})$ & Country \\
\hline$-15.9 \%$ & USA \\
$-14.4 \%$ & Japan \\
$-19.6 \%$ & Germany \\
\hline
\end{tabular}

TABLE 4

Ostrich eggshell values quoted from the literature

\begin{tabular}{|c|c|c|c|c|c|c|c|}
\hline Lab no & Ref & $\begin{array}{c}\delta^{13} \mathrm{C} \\
\% \text { o } \\
\text { PDB }\end{array}$ & $\begin{array}{l}\text { Eggshell } \\
\text { carbonate } \\
{ }^{14} \mathrm{Cage}^{*}\end{array}$ & $\begin{array}{l}\text { Other } \\
\text { material } \\
{ }^{14} \mathrm{Cage}^{*}\end{array}$ & $\begin{array}{c}\delta^{13} \mathrm{C} \\
\% \% \\
\text { PDB }\end{array}$ & Lab no. & Material \\
\hline$A-2515$ & 1 & -3.4 & $6270 \pm 50$ & $6660 \pm 320$ & -19.8 & $A-2516$ & Organic residue \\
\hline-2517 & 1 & -4.4 & $4780 \pm 50$ & & & & \\
\hline-2518 & 1 & -4.4 & $6290 \pm 150$ & & & & \\
\hline-3106 & 1 & -5.6 & $8280 \pm 60$ & $8680 \pm 450$ & -21.8 & $A-3105$ & Organic residue \\
\hline SMU-74 & 2 & & $4510 \pm 70$ & & & & \\
\hline-734 & 2 & & $7860 \pm 90$ & & & & \\
\hline-326 & 2 & -3.7 & $-7890 \pm 70$ & & & & \\
\hline-741 & 2 & & $5450 \pm 80$ & & & & \\
\hline-257 & 2 & -7.3 & $8270 \pm 80$ & & & & \\
\hline-191 & 2 & & $7710 \pm 70$ & $8130 \pm 60$ & & SMU-255 & Charcoal \\
\hline-202 & 2 & -4.6 & $8020 \pm 110\}$ & $8040 \pm 90$ & & -249 & Charcoal \\
\hline \multirow[t]{5}{*}{-189} & 2 & -7.2 & $7890 \pm 100)$ & $8080 \pm 90$ & & -252 & Charcoal \\
\hline & & & & $7970 \pm 70$ & & -240 & Charcoal \\
\hline & & & & $7930 \pm 40$ & & -208 & Charcoal \\
\hline & & & & $8010 \pm 80$ & & -203 & Charcoal \\
\hline & & & & $\mid 8120 \pm 100$ & & -199 & Charcoal \\
\hline SMU-273 & 2 & -7.3 & $6980 \pm 80^{\circ}$ & & & & \\
\hline-494 & 3 & & $8740 \pm 70$ & $8740 \pm 90$ & & SMU-489 & Charcoal \\
\hline-352 & 4 & -4.6 & $6935 \pm 90$ & $7120 \pm 150$ & & -242 & Charcoal \\
\hline
\end{tabular}

* Normalized to $\delta^{13} \mathrm{C}=-25 \%$ PDB

References

1. Long, Hendershott and Martin (1983, Table 2)

2. Haas \& Haynes $(1980$, Table A7.1, p 374/5)

3. Haas \& Haynes $(1980, \mathrm{p} 376)$

4. Wendorf \& Schild (1984, footnote 1, p 411)

Hodges and Lörcher (1967) showed by infusion experiments with tracerlabeled $\mathrm{NaH}^{14} \mathrm{CO}_{3}$ and ${ }^{45} \mathrm{CaCl}_{2}$ that the carbonate of the eggshells is not derived from the hen's blood bicarbonate. They found an uptake of ${ }^{45} \mathrm{Ca}$ ions from the blood serum during shell formation but not the adequate bicarbonate uptake. More detailed studies (Lörcher \& Hodges, 1969) suggest that the necessary $\mathrm{CO}_{2}$ is taken from metabolic $\mathrm{CO}_{2}$ generated in the hen's shell gland at the actual site of egg formation. The $\delta^{13} \mathrm{C}$ values of this metabolic $\mathrm{CO}_{2}$ are subject to the hen's diet. Table 3 shows the $\delta^{13} \mathrm{C}$ values of the protein 
carbon of chicken flesh from different countries (Nakamura et al, 1982). The higher values from the United States and Japan are due to higher $\delta^{13} \mathrm{C}$ values of $\mathrm{C} 4$ plants (especially maize) or fish-derived feed, respectively. In Germany, the diet contains more $\mathrm{C} 3$ plant material, hence, the chicken flesh is ${ }^{13} \mathrm{C}$-depleted. In this case, the $\delta^{13} \mathrm{C}$ value also of the hen's shell gland $\mathrm{CO}_{2}$ would be ca-14\% (Metzler et al, 1983). The $\mathrm{CO}_{2}$ with $\delta^{13} \mathrm{C}=-14 \%$ (Sharma \& Pillai, 1971) is in equilibrium at $30^{\circ} \mathrm{C}$ with $\mathrm{HCO}_{3}^{-}$ions of $\delta^{13} \mathrm{C}=-6.5 \%$ (Mook, 1968); carbonates formed from these $\mathrm{HCO}_{3}^{-}$ions show a $\delta^{13} \mathrm{C}$ value of ca $-5 \%$. $\delta^{13} \mathrm{C}$ values of ca $-6 \%$ can be readily explained by this mechanism. The higher $\delta^{13} \mathrm{C}$ values close to $0 \%$ seem to point towards a higher amount of carbon derived from $\mathrm{C} 4$ plants.

${ }^{14} \mathrm{C}$ dates on ostrich eggshells have been reported by Haas and Haynes (1980), Wendorf and Schild (1984), and Long, Hendershott and Martin (1983) (Table 4). They normalized ${ }^{14} \mathrm{C}$ ages to $\delta^{13} \mathrm{C}=-25 \%$, and did not find significant age differences with concurrent samples of other materials.

\section{ACKNOWLEDGMENTS}

Thanks are due the staff of the BOS Project, especially Erwin Cziesla and Werner Schuck, as well as the laboratory staffs of the ${ }^{14} \mathrm{C}$ and the ${ }^{13} \mathrm{C}$ laboratories. Part of the work was funded by DFG, Bonn and by Stiftung Volkswagenwerk, Hannover.

\section{REFERENCES}

Breunig, P, 1986, Archaeological research in the upper Brandberg: Nyame Akuma (Windhoek, SW Africa), v 27, p 26-27.

Gabriel, B, 1982, Arbeitsberichte aus der Forschungsstation Badai/Tibesti, part 5: Abschlussbericht: Berliner Geogr Abh, no. 32.

Haas, H and Haynes, C V, 1980, Discussion on radiocarbon dates from the Western Desert, in Wendorf, F, and Schild, R, eds, Prehistory of the Eastern Sahara: New York, Academic Press, p 373-378.

Hodges, R D and Lörcher, K, 1967, Possible sources of the carbonate fraction of the egg shell calcium carbonate: Nature, v 216, p 609-610.

Kuper, R, in press, The Eastern Sahara from north to south. Data and dates from the BOS-Project, in Korbusiewicz, M and Krzyzaniak, L, eds, Internatl symposium (1988), Environmental change and human culture in the Nile Basin and North Africa through 2nd millennium BC: Posen, Polish Acad Science.

Long, A, Hendershott, R B and Martin, P S, 1983, Radiocarbon dating of fossil eggshell, in Stuiver, M, and Kra, R S, eds, Internatl ${ }^{14} \mathrm{C}$ conf, 11th, Proc: Radiocarbon, v 25, no. 2, p 533-539.

Lörcher, K and Hodges, R D, 1969, Some possible mechanisms of formation of the carbonate fraction of egg shell calcium carbonate: Comp Biochem Physiol, v 28, p 119-128.

Metzler, S, Stobbe, E, Kranz, C, Schmidt, H L, Winkler, F J and Wolfram, G, 1983, Einfluss des natürlichen Isotopengehalts von Nährstoffen auf den Untergrund bei ${ }^{13} \mathrm{C}$-Atemtests: Zeitschr Ernährungswiss, v 22, p 107-115.

Mook, W G, (ms), Geochemistry of the stable carbon and oxygen isotopes of natural waters in the Netherlands: Ph D dissert, Univ Groningen.

Nakamura, K, Schweller, D A, Winkler, F J and Schmidt, H L, 1982, Geographical variations in the carbon isotope composition of the diet and hair in contemporary man: Biomed Mass Spectrometry, v 9, p 390-394.

Sharma, T and Pillai, N V, 1971, Oxygen and carbon isotope composition of chicken egg shell carbonate: Indian Jour Chem, v 9, p 456-458.

Wendorf, F and Schild, R, 1984, Chap 17, Conclusions, in Close, A E, ed, Cattle keepers of the Eastern Sahara. The Neolithic of Bir Kiseiba: Dept Anthropol, Southern Methodist Univ, Dallas, p 404-428. 